\title{
RÍO-MAR-DESIERTO: CLAVE / ANTICLAVE
}

\author{
Rafael Morales Astola
}

\section{RÍO-MAR-DESIERTO}

A ti he llegado, riomar, desiertoriomar de onda y de duna, de simún y tornado, también, dios; mar para el pie y el brazo, con el ala en el brazo y en el pie.

Nunca me lo dijeron.

Y llego a ti por mí en mi hora, y te descubro; te descubro con dios, dios deseante, que me dice que eres siempre mío $y$ te me ofreces en sus ojos como una gran visión que me faltaba.

Tú me das movimiento en solidez, movimiento más lento, pues que voy hacia mi movimiento detenido; movimiento de plácida conciencia de amor con más arena, arena que llevar bajo la muerte (la corriente infinita que ya dije) como algo incorruptible.

Por ti, desierto mar del río de mi vida, hago tierra mi mar, me gozo en ese mar (que yo decía que no era de mi tierra); por ti mi fondo de animal de aire se hace mas igual; y la imagen 
de mi devenir fiel a la belleza

se va igualando más hacia mi fin,

fundiendo el dinamismo con el éstasis.

Mar para poder yo con mis dos manos

palpar, cojer, fundir el ritmo de mi ser escrito, igualarlo en la ola de agua y tierra.

Por mí, mi riomardesierto,

la imagen de mi obra en dios final

no es ya la ola detenida,

sino la tierra sólo detenida

que fue inquieta, inquieta, inquieta.

\section{JUAN RAMÓN JIMENEZ}

\section{Juan Ramón: el río.}

Símbolo nacido tan temprano, en todo volcán o sombra de poesía, en todo tiempo de literatura y expresión del vivir. El río. Con aguas claras. O sucias. De poetas limpios o malditos. De pasión abierta o de razón oculta. De ceguera épica o tormento malsano y venenoso. De Juan Ramón, único. Como tanto quiso. En un verso encontramos la clave (o anticlave) para comprender (¿descomprender?) este poema. Tal vez su obra. La obra: Dios deseado y deseante. Al comentar cualquier poema de este libro, estamos tentados a caer en la reinterpretación de ciertos criterios que, con el tiempo, se han convertido en «rigurosos» o «sistemáticos» lugares comunes: la certeza o no de esa rara experiencia mística, la invención del Dios, el milagro de la palabra en español, el éxtasis... Todo es verdad. En la obra misma. Pero sabemos que un poema, una novela, un relato, no termina sino en el lector. Y como tal, quizá más aventajado que otro más ingenuo y desnudo, me aproximaré a «Río-mar-desierto». Sin querer ver nada. Queriendo sentir todo.

El verso en cuestión me produjo desasosiego y ansia de acertar en su significado. Sánchez Barbudo no tiene reparos en reprochar a Juan Ramón, refiriéndose a este poema, el haber practicado un «barroquismo, adorno y encubrimiento inútiles, sin alcanzar por ello belleza alguna de ninguna clase». Si difícil es para este crítico descifrar ciertas oscuridades de Juan Ramón, más difícil sería para mí descifrar qué entiende él por útil / inútil en poesía de los demás. Y ahora, el verso elegido, oscuro y hermoso:

\section{desierto mar del río de mi vida}

El tópico, en general: el río, nuestra vida, corre hacia el mar, la muerte o, en ocasiones, la plenitud. El verso denota algo totalmente diferente: el desierto y el mar son «del río» y están, por consiguiente, dentro de la vida del poeta. Tres son los grandes símbolos que aparecen en el poema y que le dan título: mar, desierto y río. Espacios. En el verso 21, Juan Ramón aúna los espacios mayores (y contrapuestos, desde un punto de vista realista) adjetivando uno de ellos. De hecho, a lo largo del poema no hace sino fusionarlos con un procedimiento de 
metáfora sobre metáfora. Ambos espacios mayores, convertidos en uno, se integran en un espacio menor: río. La vida del poeta. Juan Ramón. Su obra. Sánchez Barbudo parece atinar cuando afirma que en los versos finales Juan Ramón hace referencia clara a su obra poética. Creo que acierta sólo en parte. El «andaluz universal», con luz hasta en su sombra, dice sobre su llegada al puerto de Buenos Aires en 1948: «No soy ahora un deslenguado ni un desterrado, sino un conterrado». Si confiamos en la sinceridad de su emoción tan elevada, tan sentida a partir de los demás y no desde algo propio y creado artificiosamente como felicidad, no exagero al creer que el poeta, si bien en los versos finales habla de su obra, no habla de ella en sí misma, sino también conterrada («no es ya la ola detenida, / sino la tierra sólo detenida»). Juan Ramón descubre un sentimiento colectivo en lo español. A través de la palabra. Como siempre casi todo: «Todo era por mi lengua, por la lengua en que había escrito lo que ellos habían leído». Luis Cernuda, en sus Estudios sobre poesía española contemporánea, contribuye a fijar la imagen de un Juan Ramón encerrado en su torre de marfil. Pero, como apunta Gilbert Azam, Juan Ramón era un hombre muy afectado por enfermedades psíquicas, que le alejaban del tumulto social de su tiempo. Azam señala, además, ciertos actos del poeta que expresan su preocupación por los desprotegidos y humildes. Creo que Juan Ramón, a partir de 1948, fraterniza su obra de una manera que ni siquiera él mismo hubiera jamás sospechado. Ya en Bonanza (1911-12) escribía un hermoso poema impregnado de solidaridad y de hondo humanismo, del cual extraemos estos versos reveladores:

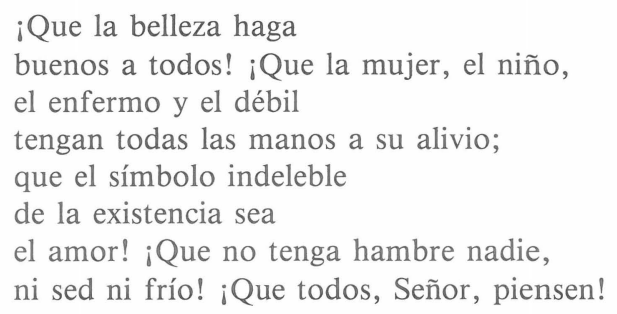

En Dios deseado y deseante el poeta se sumerge en un ámbito de comunicación con el dentro y con el fuera («Y llego a ti por mí en mi hora, y te descubro» v. 7), con la naturaleza y con la divinidad ( «A ti he llegado, ríomar, / desiertoriomar de onda y de duna, / de simún y tornado, también, dios» vv. 1-3), con lo bello y con una «conciencia / de amor con más arena» (vv. 15 y 16), de amor, quizá más abarcador y más amplio. En el poema de Bonanza, arriba indicado, la belleza es la fuerza transformadora capaz de construir un mundo mejor para todos. Es precisamente «a Dios en la conciencia de lo bello» lo que Juan Ramón dice encontrar en su llegada a Buenos Aires en 1948. Un dios, estimo, solidario y tierno, aliado a una vida nueva y más humana. El río que es el poeta, donde mar y desierto, dios y naturaleza, todo y uno se funden, no da cabida - ini mucho menos! - a una especie de conciencia política, que le compromete a amar a la humanidad, sino a una actitud feliz que le hace vivible la fe en la belleza posible de la vida. Se trata de un posicionamiento ético, por medio de lo puramente estético, un «devenir fiel a la belleza» (v. 27). Ese profundo sentirse «colectivo», 
integrador, total, aparece con absoluta transparencia en los primeros versos de «El todo interno», también poema de Dios deseado y deseante: «He llegado a una tierra de llegada. / Me esperaban los tuyos, deseado dios; / esperaban los míos / que, en mi anhelar de tantos años tuyos, / me esperaron contigo, / conmigo te esperaron».

Río de humanidad alegre en el yo del poeta, también mar, también desierto. Lo inmenso y lo infinito en el espacio menor de un ser solo y feliz.

\section{Juan Ramón: El desierto-el mar}

Ya en el apartado anterior hice alusión a lo que he dado en llamar «procedimiento de metáfora sobre metáfora». Mar y ola son términos, de por sí, evocadores. En poesía arrastran, además, valores adquiridos por una determinada tradición poética y cultural. El mar: plenitud, inmensidad, muerte. Las olas: movimiento, inquietud, travesía de amor. Plantar ambas palabras en un poema implica sugerir múltiples realidades (estados de ánimo, sentimientos, mundos...) que el lector se presta, de inmediato, a reconocer. Juan Ramón matiza, reelabora profundamente estos conceptos. De este modo, la simbología se hace más honda, ambigua, más atractiva para la interpretación personal y única.

A «mar» $\mathrm{y}$ «ola» Juan Ramón añade «desierto» y «duna». Tal vez no debiera decir añadir, sino insertar. Los espacios y elementos de la naturaleza que el poeta fusiona en «río» lo podemos ver, gráficamente, del siguiente modo:

$\begin{array}{ll}\text { MAR } & \text { DESIERTO } \\ \text { ola, onda } & \text { duna } \\ \text { agua } & \text { arena (tierra) }\end{array}$

$$
\text { RÍO }
$$

Del poema extraemos varios ejemplos que reflejan dicha fusión: «mar para el pie y el brazo» (v. 4), es decir, mar para caminar y nadar; «ola de agua y tierra» (v. 32); «no es ya la ola detenida» (v. 35), la duna sola y quieta del desierto, como el poeta tal vez debió sentirse antes de encontrar «a Dios en la conciencia de lo bello».

En el gráfico he puesto «tierra» entre paréntesis porque, en el poema, este término ofrece cierta confusión. Regreso al verso ventiuno: «desierto mar del río de mi vida». El desierto se hace mar. Desierto y mar se hacen río. El río se hace vida y obra del poeta. El poeta, a partir de la experiencia de su llegada a Buenos Aires en 1948, sin la cual él confiesa que hubiera sido imposible el éxtasis que luego manifestaría en Dios deseado y deseante, es «conterrado». La tierra, por consiguiente, es el gran espacio donde todo está y donde todo es, dios y poeta incluidos. De este modo, creo, se comprenden los versos 22, 23 y 24: «hago tierra mi mar, / me gozo en ese mar (que yo decía / que no era de mi tierra)». Este mar es nuevo en Juan Ramón, parece refundido, mirado con otros ojos. Por igual motivo comprendemos los versos 34,35 y 36 : «la imagen de mi obra en dios final 
/ no es ya la ola detenida, / sino la tierra sólo detenida». Su obra no es ya río, ola, mar, ni desierto ni duna. Solamente tierra. Y no hace falta más, porque tierra es todo. No obstante, un empleo de dicho término en el poema me lleva a la confusión:

igualarlo en la ola de agua y tierra (v. 32)

Contrapone «tierra» a «agua», en vez de decir, como en los versos 16 y 17, «arena». Esto me indujo a colocar «arena» $\mathrm{y}$ «tierra» en un mismo estadio del gráfico. Un poema no puede ser exacto como una operación matemática. Y mucho menos puede ser exacto el comentario del poema. De cualquier forma, pienso que puede entenderse como un elemento más de la naturaleza que se hace tierra, en este caso, la ola.

\section{Juan Ramón: la tierra.}

El dios de la tierra. Lo bello en la tierra. La conciencia de amor y felicidad en la tierra. Juan Ramón regresa a la tierra. El oir español en Buenos Aires, cuando llega a esta ciudad en 1948, le lleva a sus orígenes. La tierra como madre, como principio de la vida. Para el psicoanálisis, el deseo de dios no es más que la nostalgia de ese estado de plenitud y de equilibrio que todo hombre siente en el seno materno. En el poema «Río-mar-desierto», todos los espacios, todo el movimiento que se realiza en esos espacios, confluyen en «la tierra sólo detenida». Llegan al origen. Llegan a ser el origen mismo. El poeta, con su obra, se convierte en origen de sí y de todo. Creo ineludible este juicio de Anais Nin:

«El deseo de regresar al útero puede, si es un deseo creador, transformar el mundo entero en un útero que lo incluye todo, que lo abarca todo. Como no puede regresar al útero, el artista se convierte en útero».

A partir de este criterio, comprendo que el orden en la fusión de los espacios («Río-mar-desierto», «riomar», «desiertoriomar», «riomardesierto») no es realmente importante, pues tiende a reflejar únicamente el movimiento creador, y convulsivo interiormente, del poeta.

La importancia de la llegada al lugar esperado y esperante lo notamos de nuevo en el poema «En lo mejor que tengo»: «dios deseado y deseante, / alumbrando de oros distintos mi llegada; / la llegada de éste que soy ahora yo, / de éste que ayer mismo yo dudaba / de que pudiera ser en ti como lo soy». El poeta llega, de cualquier forma, regresando. Azam habla de la «gratuidad del don recibido» como característica de toda experiencia religiosa. El éxtasis de Juan Ramón no me parece recibido gratuitamente. El poeta estaba predispuesto y preparado para recibir el don, para darse el don. Con el riego de parafrasear, puedo decir que el don del «hallazgo», de la fusión mística, es ofrecido al poeta, pero también es descubierto por él: 
te descubro con dios, dios deseante, que me dice que eres siempre mío $\mathrm{y}$ te me ofreces en sus ojos como una gran visión que me faltaba.

(vv. 8-11)

Me pregunto si se trata realmente de la exposición religiosa (o pseudoreligiosa) de una determinada experiencia, o bien no es más que la exaltación de un deseo enorme de amar. Un amar en sí mismo sencillo, pero complicado por la fecunda formación intelectual y religiosa de Juan Ramón. Otros críticos han señalado ya la influencia de la teología modernista y de Unamuno en el poeta gaditano. Unamuno, en Recuerdos de niñez y de mocedad, afirma que la «fecunda edad» de la poesía es la niñez. En el poema «Con la cruz del Sur» Juan Ramón habla de su «volver al niñodios» que fue un día. La idea de un dios inmanente. La idea de un dios al nivel del pensamiento. La idea de un dios renacido en el niño de ayer. La idea de un dios no presente en las iglesias, sino en el puro corazón y único del universo. De la tierra nace ese «niñodios» y a la tierra regresa, como poeta, más alto, más libre, para alcanzar esa «gran visión» que le falta: dios y la belleza. En la tierra, en el seno materno, Juan Ramón encuentra su alimento para amar. Interesante son estos versos del poema arriba aludido: «Y abajo, muy debajo de mí, en tierra subidísima, / que llega a mi exactísimo ahondar, / una madre callada de boca me sustenta, / como me sustentó en su falda viva, / cuando yo remontaba mis cometas blancas». En Conversaciones con Juan Ramón Jiménez, de R. Gullón, el poeta mismo se pregunta: «¿Qué es Dios sino un temblor que tenemos dentro, una inmanencia de lo inefable?». Un temblor, pues. Un temblor, y dentro, pero expresado, en Dios deseado y deseante, hacia dentro y hacia fuera. Por ello, el «fondo de animal» de Juan Ramón parece, a veces, el mundo exterior; otras veces, parece el alma. En el verso 25 de «Río-mar-desierto» («por ti mi fondo de animal de aire se hace / más igual...») pienso que se refiere al alma, al «dentro». El aire como algo intangible, invisible, semejante al espíritu humano.

La fuerza del poema está en ese «llegar», por un camino de «riomardesierto», a la «tierra», a lo primero, donde el «niñodios» se acuna en «la conciencia de lo bello». En Dios. En el amor. Y sueña la luz en todos los seres y cosas.

Un camino hacia la obra «conterrada». Un camino que tiende a quedar en un final ( « No la toques ya mas, / que así es la rosa!»), después de un proceso creador meticuloso y compacto. A tal proceso, quizá, se refieran los versos 12 , 13 y 14 :

Tú me das movimiento en solidez, movimiento más lento, pues que voy hacia mi movimiento detenido

Movimiento interno. Movimiento externo. El yo. La tierra. El todo, o Dios. O el amor. Dinamismo de la risa en el alma, de la alegría en la mente. Inquietud que culmina en reposo. Que culmina en poema, en idioma de sus lectores y oyentes, en sensación múltiple y abierta, como la herida fecunda y feliz de la tierra. 


\section{BIBLIOGRAFÍA}

AzAm, G.: La obra de Juan Ramón Jiménez. Editora Nacional, Madrid, 1983.

Gullón, R.: El último Juan Ramón Jiménez. Alfaguara, Madrid, 1968.

SANTos Escudero, C.: Símbolos y Dios en el último Juan Ramón Jimenez. Gredos, Madrid, 1976.

SÁnchez BARbudo, A.: La segunda época de Juan Ramón Jiménez (1916-53). Gredos, Madrid, 1962. 
